\title{
Hong Kong and Macau Special Administrative Regions: The Downfall of The "One Country, Two Systems" Policy
}

\author{
Arnaldo M.A. Gonçalves \\ Researcher in the Institute of Political Studies \\ Catholic University of Portugal \\ Portugal
}

\begin{abstract}
According to the principle "One Country, Two Systems", approved and implemented by Deng Xiao Ping, Hong Kong and Macau would continue as separate autonomous parts of China for 50 years after returning to China. In terms of their Basic Laws, both territories have been governed as Special Administrative Regions (SARs) since the late 1990s. Notwithstanding the guarantees given to the British and Portuguese governments when negotiating the respective joint declarations, these guarantees were eroded as China changed its policy, progressively dismantling the foundations of autonomy by using a combination of political pressure, interference in the affairs of the SARs, and reinterpretation of the Basic Laws in line with China's very circumscribed notion of sovereignty. These dramatic changes mean, unequivocally, the eroding of the "One Country, Two Systems policy" and the demolishing of Deng Xiao Ping legacy.
\end{abstract}

Keywords: China, Hong Kong, Macau, Deng Xiao Ping, One Country, Two Systems, Socialism, Basic Law.

\section{The historical context}

Hong Kong is located to the east of the Pearl River estuary in the south of the south coast of China. The city is bordered by Guangdong Province to the north and the South China Sea to the east, south, and west. In the late Qing Dynasty the imperial government entered into conflict with Great Britain because of the opium trade monopolized by the British. Starting in the middle 1700s, Great Britain began trading opium grown in India in exchange for silver from Chinese merchants. Opium was illegal in England but was used often by the Chinese in traditional medicine (Roblin, 2016). The British began to ship tons of the drug using commercial loopholes and smuggling to get around the ban (Xiao, 2001, pp. 65-66). Consumption of opium skyrocketed in China, alarming the Daoguang emperor because of the millions of drug addicts. In 1839 a new imperial commissioner instituted laws banning opium throughout China, arrested numerous dealers, and seized the drug in Chinese harbours and had all the stock thrown into the sea.

The British government intervened after angry British traders reclaimed compensation for the lost drugs (Roblin, 2016). This signalled the start of the Opium War from 1840 to 1842, in which the Qing Dynasty was defeated and forced to sign the Treaty of Nanjing of August 1842. According to Article Three of the treaty, China was obliged to cede Hong Kong to Britain (Xiao, 2001, pp. 65-66). The Qing army was defeated in a Second Opium War, leading to the signing of the Treaty of Beijing between China and Great Britain. Accordingly, the southern part of the Kowloon Peninsula and Stonecutters Island was ceded to Britain. That area was to become enlarged when the British negotiated with the Chinese, in June 1888, the Special Articles for Enlargement of the Hong Kong Boundary. This led to the leasing to the British of an area of the Kowloon Peninsula, south of the Shengzhen River, and around 230 adjoining islands. This area was leased for 99 years (1898 to 1987) and become known as the New Territories (Xiao, 2001, p. 66). Hong Kong Governor Murray MacLehose raised the issue of Hong Kong with Chinese leader Deng Xiaoping on his first official visit to China. Deng emphasized that China would reassert sovereignty over the "special region" after June 30, 1997 (Reuters, 2007).

Macau is a city on the coast of Guangdong Province situated on an arm of land that forms a peninsula of two to three miles in circumference. The navigator Jorge Álvares in 1513 landed on an island, Tamão, in the vicinity of what is now the city of Guangzhou. Hence in 1535 Portuguese traders obtained the rights to anchor their ships in Macau's harbour and to conduct trading activities. The Portuguese discovered the vast size and importance of China and the important location of Macau in the crossroads of the maritime trade routes from the Portuguese possession of Melaka to the Chinese coast and Japan (Willies, 2002, p. 57). By 1555 Macao had become an important centre in the trade of gold, silver, silk, and porcelain between Goa, China, and Japan. Following the First Opium War, Portugal occupied the deserted islands of Taipa and Coloane in 1851 and 1854, respectively (Scott, n.d.). On December 1, 1887, the Portuguese crown and the Qing emperor signed the Sino-Portuguese Treaty of Amity and Commerce (also called the Treaty of Peking), under which China ceded "the right of perpetual occupation and government of Macau by Portugal in compliance with the prescriptions of the Protocol of Lisbon" (Fundação Jorge Alvares, n.d.). 
Portugal was obliged "never to alienate Macao without previous agreement with China", and therefore Macau became an overseas territory. Following the proclamation of the People's Republic of China in 1949, the Communist government stated that the Sino-Portuguese Treaty was invalid and an "unequal treaty" imposed by Portugal on China, taking advantage of the defeat of the Qing government in the Opium War (Ministry of Foreign Affairs of the PRC, n.d.;Tam, n.d.). However, Beijing would not settle the issueimmediately, allowing the continuity of "the status quo" until a more appropriate time emerged. Following the 1974 Carnation Revolution, Portugal's democratic government expressed the will to work on a negotiated solution with China concerning Macau (Fernandes, 2017). The Chinese government was extremely cautious and at first refused the handover of Macau. In 1976, Macau was redefined by the new Portuguese Constitution (Article 5) as "Chinese territory under Portuguese administration ruled by a statute in conformity to its special situation", therefore enjoying a large measure of administrative, financial, and economic autonomy (Fischer \& Klatte, 2011; Parlamento Português, n.d.).

Since the founding of the People's Republic of China, China's Communist government has reiterated the will to regain or resume sovereignty over Hong Kong, Macau, and Taiwan, preferably through a peaceful settlement (Ministry of Foreign Affairs, n.d.). The First Opium War became impressed in Chinese identity as the beginning of the "Century of Humiliation", a time that was closed in 1949 when Mao proclaimed the founding of the People's Republic of China (Roblin, 2016). In the 1970s the representative of China to the United Nations sent a letter to the chairman of the Decolonization Commission of the UN stating that "Hong Kong and Macau are parts of the territory of China under the respective occupation of Britain and Portugal" and expressing the will to solve the problems of both territories "within the scope of Chinese sovereignty" (Xiao, 2001, p. 65). In the view of China these territories were unsuitable to the application of the Decolonization Declaration as nondependent territories and therefore could not be subject to a process of independence from the colonial powers (Xiao, 2001, pp. 65-66). This position was confirmed by a resolution of the Commission on Decolonization on June 15, 1972, proposing to the UN assembly that Hong Kong and Macau would be eliminated from the name-list of Non-Self-Governing Territories. This proposal was adopted on November 8, 1972, in the form of a resolution of the UN assembly (Willets, 2013).

As it has been argued, recently, by supporters of the independence of Hong Kong, the concrete implications for Hong Kong (and Macau) of that resolution were never under the scrutiny of the UN (Wong\& Ngo, 2016). The former colonial powers acknowledged that it was not the time to opt for a process of independence of Hong Kong or Macau, as China would strongly reject it. Hong Kong and Macau continued to be British and Portuguese dependent territories, respectively, for the next 25 and 27 years, until the transfer of sovereignty was completed.

\section{The "One Country, Two Systems" policy and the creation of the Special Administrative Regions}

A definitive solution to the situations of Hong Kong (and Macau) would be the consequence of two impulses: the need to clarify the situation of the New Territories as its leasing was about to finish in June 1997 and the determination of the reformist leader Deng Xiaoping that China would resume its sovereignty over all territories occupied by foreign powers before the passing of the century. That convergence led first to the negotiation of the Joint Declaration of the Government of the United Kingdom of Great Britain and Northern Ireland and the Government of the People's Republic of China on the Question of Hong Kong (Joint Declaration, 1987) and second to the negotiation of a similar treaty by the Portuguese and Chinese governments (Macau Special Administrative Region, n.d.). The signing and interpretation of both treaties ought to be seen in the light of the "One Country, Two Systems" policy.

In talks with a foreign delegation on January 11, 1982, Deng Xiaoping alluded, for the first time, to the idea of "one country, two systems" by mentioning the Taiwan situation and the need to facilitate a peaceful reunification with the mainland. Deng acknowledged that dual systems prevailing in mainland China and Taiwan needed to be preserved, provided that Taiwan would not undermine the mainland's system and China would not undermine Taiwan's system (Wen, 2009). Two years later, in a meeting with a delegation of businessmen from Hong Kong, Deng declared, "After China resumes the exercise of its sovereignty in Hong Kong in 1997, Hong Kong's current social and economic systems will remain unchanged, its way of life and its status as a free port and international trade and monetary centre will remained unchanged and it can continue to maintain and develop economic relations with other countries and regions" (Deng Xiaoping, 1987, p. 48). He went on to say that we are pursuing a policy of "one country, two systems". More specifically this means that within the People's Republic of China, the mainland with its one billion people will maintain the socialist system while Hong Kong and Taiwan continue under the capitalist system (...) our policy will remain unchanged for a long time to come, but this will not affect socialism in mainland. The main system in China must be socialism (Deng Xiaoping, 1987, p. 49).

On December 19, 1984, in a meeting with a British delegation headed by PrimeMinister Margaret Thatcher, the same idea was reaffirmed. When Mrs. Thatcher said that "the stroke of genius in bilateral negotiations had been the concept of One Country Two Systems", 
Deng ironically replied that "the credit should go to the Marxist historical dialectics or to seeking truth from the facts and to solve the Hong Kong question peacefully an answer that satisfied China, Britain and the people in Hong Kong" (British Embassy, 1984). He added that "the imposition of socialism on the territory would have been easy but it would not have been acceptableto Britain or the people of Hong, nor even if it had been acceptable would it have preserved Hong Kong's prosperity". Deng highlighted that the concept of "one country, two systems" had been devised originally to solve the Taiwan issue and not the Hong Kong issue, but the Chinese leadership was convinced that it would work and the next 63 years would prove the concept. As people harboured doubts about whether China would honour the agreement, Deng directly addressed the doubts by replying that "China had always honoured its commitments" (British Embassy, 1984).

PrimeMinister Thatcher replied that "our two countries had signed the agreement in the eyes of the world", so she was sure that China would therefore honour the agreement, and "so would Britain", but as some people in Hong Kong harboured doubts "they need to be assured and it was helpful to explain the reasons why Chinese policy would not change" (British Embassy, 1984). Although time has the effect of blurring the precise boundaries of political statements, it is interesting to recognize today that Deng Xiaoping was convinced that China had the military capability to take possession of Hong Kong by force even with Britain political opposition. Even so the military solution would not have satisfied a purpose of peaceful reunification esteemed by Britain and by the Hong Kong people. It is remarkable that China's reformist leader held in such high regard the interests of the Hong Kong people, putting his prosperity as equivalent to the objective of national reunification of all Chinese territories. It may be counter-argued that Deng admitted that the "One Country, Two Systems" policy would facilitate the reunification with Taiwan, a conclusion that later circumstances would prove unrealistic.

On December 4, 1982, the Fifth Session of the Fifth National People's Congress (NPC) endorsed a new constitution of the People's Republic of China. Its Article 31 prescribes that "The state may establish special administrative regions when necessary. The systems to be instituted in special administrative regions shall be prescribed by law enacted by the National People's Congress in the light of the specific conditions" (National People's Congress of the People's Republic of China, 2004). In early 1983, the Chinese government formulated 12 principles regarding the question of Hong Kong, which became known as the "12 Principles" (Information Office of the State Council, 2014).

Those principles (Information Office of the State Council, 2014) are these: (1) resumption of the exercise of sovereignty over Hong Kong as of July 1, 1997; (2) establishing a special administrative region in Hong Kong under the direct authority of the Central People's Government and enjoying a high degree of autonomy; (3) assignment to the Hong Kong Special Administrative Region (HKSAR) of legislative and independent judicial power, including that of final adjudication and the guarantee that the laws, decrees, and regulations in force in Hong Kong would remain basically unchanged; (4) the government of the HKSAR would comprise local inhabitants and the principal officials would be selected by election or through consultations held locally and be appointed by the Central People's Government; (5) the social and economic systems in Hong Kong would remain unchanged, as would the lifestyle;freedoms, including those of speech, the press, assembly, association, travel, movement, correspondence, and religious belief would be ensured in the HKSAR; (6) the HKSAR would retain the status of a free port and a separate customs territory; (7) the HKSAR would retain the status of a financial centre, and its markets would continue for foreign exchange, gold, securities, and futures; (8) the HKSAR would have independent finances; (9) the HKSAR may establish mutually beneficial economic relations with the United Kingdom, whose economic interests in Hong Kong would be given due regard; 10) using the name "Hong Kong, China," the HKSAR may on its own maintain and develop economic and cultural relations and conclude relevant agreements with states, regions, and relevant international organizations; the government of the HKSAR may itself issue travel documents for entry into and exit from Hong Kong; (11) the maintenance of public order in the HKSAR would be the responsibility of the government of the HKSAR; and (12) these policies would be stipulated in the Basic Law of the HKSAR by the NPC of the People's Republic of China (PRC), and they would remain unchanged for 50 years.

On April 4, 1990, the Third Session of the Seventh NPC passed the Basic Law of the Hong Kong SAR of the PRC and made the decision to establish the HKSAR (National People's Congress, 2007). The law was designated "Basic Law" and was drafted in accordance with the constitution of the PRC. It stipulated the system and policies to be instituted in the HKSAR in its first chapter. The Basic Law included an important injunction thatthe Hong Kong SAR is an inalienable part of the PRC (Article 1). On the same date, the president of the PRC, Yang Shangkun, promulgated the Basic Law by his Decree No. 26 (Government of the Special Administrative Region of Hong Kong, 2017). On 1 July 1 1997, the Chinese government resumed its exercise of sovereignty over Hong Kong, the HKSAR was established, and the Basic Law came into effect. On the same day more than 4,000 troops from China's People's Liberation Army crossed the border into Hong Kong in the early hours of the morning. Chief Executive Tung Chee-hwa and the Provisional Legislative Council were sworn in later in the day (Reuters, 2007). 
On December 20, 1999, the Chinese government assumed formal sovereignty over Macau and established the Macau Special Administrative Region of China (MSAR). The Basic Law of the MSAR was adopted at the First Session of the Eighth National People's Congress on March 31, 1993 and promulgated by Order No. 3 of the president of the PRC on March 31, 1993. The principles guiding the MASR follow basically the same principles outlined in the Hong Kong SAR (Article 1 through Article 11 of Macau Basic Law). Article 1 also says thatthe MASR is an inalienable part of the PRC (University of Macau, $n / d$ ).

In summary, through the practical expedient of enacting two Basic Laws for Hong Kong and Macau, the PRC ensured that both SARs were in compliance with the Chinese constitution, namely that China is a unitary state and Hong Kong and Macau are integral parts. China guaranteedthat the socialist system is the basic system of the PRC but that the HKSAR and MSAR may maintain their capitalist systems for 50 years (Article 9, PRC constitution). The precise typology of the SARs was to be defined by law enacted by the NPC following the resumption of sovereignty (Articles 30 and 31, PRC constitution).

\section{Capitalist and liberal enclaves within a socialist state}

What makes the situation of the Hong Kong and Macau SARs original in the history of comparative political systems and international public law is the aggregate of characteristics that allow those territories to act as quasi-states within the logic of a unitary and socialist state. They are basically five: (1) political, legislative, and judicial autonomy allowed to these regions; (2) the existence of organs of local government taking decisions with autonomy in the interest of their populations and without interference from the central government; (3) the enjoyment of freedoms and civil and political rights preserved by the International Covenants of Human Rights fully applicable into the SARs; (4) recognition of the power of the regions to establish a fullspectrum of relationships with regions and states in accordance to local interests; (5) the status of the Basic Laws as "mini-Constitutions" exempting the SARs from the application of the national constitution's regulations related to the socialist nature of the state ${ }^{1}$ (Chapter 1 of the Hong Kong Basic Law and of Macau Basic Law).

The main counterweights of this large spectrum of autonomy are the recognition that both territories are inalienable and integral parts of the PRC and are therefore bounded in guarantying China's sovereignty over all Chinese territory. Second, the SARs are not submitted to the leadership of the Chinese Communist Party, in all its public and private dimensions, as it occurs in mainland China. Third, the relationship of the organs of the SARs and the central authorities are contained in a specific chapter of both Basic Laws according to the following principles: (1) the SARs are subordinated directly to the central PRC government; (2) the central PRC government should handle the foreign affairs related to the SARs, but each region is authorized to "conduct relevant external affairs on its own"; (3) the central PRC government will guarantee the defence of the SARs but the local governments "are responsible for the maintenance of public order"; (4) laws enacted by the local legislatures have to be reported to the Standing Committee of the NPC for the record; the laws that the national legislature considers not in conformity with the Basic Law should be returned to the SAR for reconsideration; (5) only the national laws listed in the Annex to the Basic Laws should be applied in the regions; (6) local courts are absolutely independent and may decide in final adjudication; they have no jurisdiction over acts of state such as defence and foreign affairs; (7) no department of the central PRC government, provincial, autonomous regions or municipalities may interfere in the affairs of the SAR; (8) the SARs will enact laws to prohibit acts of treason, secession, sedition, and subversion against the central PRC government; (9) the land and natural resources in the region shall be state property, except for private land recognised as such.

If we look at the reality of autonomous regions in the context of unitary states such as Portugal ${ }^{2}$, Spain $^{3}$, or France, China's SARs have more extensive powers of governance that bring them close to the legal status of member states within federal republics such as the United States or Germany. Even in this latter context, the states in a federation are not allowed to engage in external relations with foreign states without being integrated in a national representation; local courts don't have the competence of final adjudication; and there aren't border controls in these subregional entities. China has a tradition of harbouring autonomous regions as a way to accommodate ethnic minorities' distinctive cultures, dialects, and modes of communitarian representation (check Charter I).

\footnotetext{
${ }^{1}$ Annex III of Hong Kong Basic Law contains 12 pieces of national laws. They include the Nationality Law of the People's Republic of China; the Law of the People's Republic of China on the Garrisoning of the Hong Kong Special Administrative Region; and the Law of the People's Republic of China on the Exclusive Economic Zone and the Continental Shelf.

${ }^{2}$ Portugal has two autonomous regions, Madeira and Azores.

${ }^{3}$ Spain has 17 autonomous communities and two autonomous cities. The autonomous communities are led by regional governments that direct the educational, health, social services, cultural, and urban development and some case policing. 


\section{Charter I}

Autonomous Regions of China

\begin{tabular}{lll}
\hline Rank & Autonomous Region & Population \\
\hline 1 & Guangxi & $46,026,600$ \\
2 & Inner Mongolia & $24,706,321$ \\
3 & Xinjiang & $21,815,815$ \\
4 & Ningxia & $6,620,000$ \\
5 & Tibet & $3,180,000$ \\
\hline
\end{tabular}

Source: www.worldatlas.com

In the case of Hong Kong and Macau, these territories serve as national borders for aliens who arrive at the respective airports or ports and for aliens and Chinese nationals who enter Hong Kong and Macau from mainland China. Article 22 of Hong Kong Basic Law stipulates, "For entry into the Hong Kong Special Administrative Region, people from other parts of China must apply for approval. Among them, the number of persons who enter the Region for the purpose of settlement shall be determined by the competent authorities of the Central People's Government after consulting the government of the Region" (Government of Hong Kong Special Administrative Region of Hong Kong, 2017). A similar legal instruction exists in the case of Macau.

\section{Map I}

\section{Hong Kong and surrounding areas}

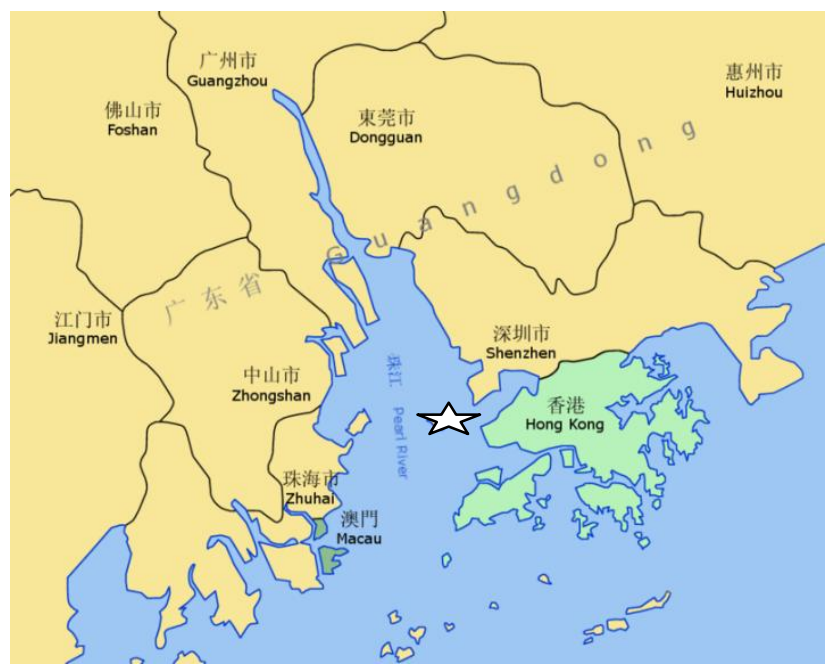

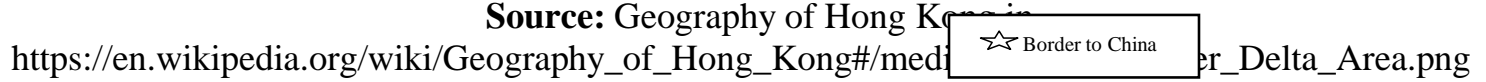

It is interesting to note the explanation given by a Chinese scholar for restricting the entry of Chinese mainlanders to Hong Kong (and by extension to Macau): "for entry into the HKSAR people from other parts of China must apply for approval and among them the number of persons who enter the Region for the purpose of settlement shall be determined by the competent authorities of the Central's People Government after consulting the government of the Region. He added"Hong Kong is not large it is not on its interest to have many people coming in from the Mainland, otherwise it will be swamped" (Xiao, 2001, p. 138).

Hong Kong and Macau inhabitants also enjoy specific civil and political rights. The International Covenants of Social and Political Rights form part of the fundamental laws of Hong Kong and Macau (Ghai, 2003, XIV). The Covenant on Civil and Political Rights guarantees many democracy-related rights such as free expression, association, and peaceful assembly and protects the right of every citizen to take part in the conduct of public affairs, the right to vote and to be elected, and the right to have access to public service (as Article 30 of the HK Basic Law guarantees) ${ }^{4}$.

\footnotetext{
${ }^{4}$ Articles 25 to 44 of Macau SAR Basic Law. See University of Macau (n/d). Basic Law Macau. Retrieved from http://www.umac.mo/basiclaw/english/main.html
} 
Thus, in conclusion, China's laws treat Hong Kong and Macau as special territories, entrusting local authorities with important powers of governance thatsupport its autonomy, allowing measures ofpopular government and not fealty to the provincial authorities.

This recognizes their specific role in China's national context as they act as "islands" governed by Western political and economic values, opposed to the official doctrine in continental China. This bestowal of broad autonomy is not without difficulties. As a scholar accurately said, the nature of Hong Kong as a special region of China "introduces complexity and several layered authorities; it produces varying degrees of identity and entitlements (...) autonomy is based on local self-government and that implies a form of local 'citizenship' excluding other citizens from full participation"(Ghai, 2003, XVIII).

The first 20 years of history of the Hong Kong SAR has put to the test most of the guarantees given by Chinese authorities when they negotiated the joint declaration with the British and when they presented their project of a Basic Law for Hong Kong (Chan \& Clark, 1991, p. 92; Davies, 1998, pp. 127-146). The greater challenge enhanced by the Basic Law are the criteria and procedure for nomination of the chief executive; the composition of the legislature and the ratio of legislators who are direct-elected, elected by functional districts, and appointed by the chief executive; the process of interpreting and implementing the Basic Law and the jurisdiction of the local judiciary; and the enforcement of the covenants of human rights in Hong Kong, considering that the PRC constitution speaks of rights and duties of citizens, bringing about contingent notions of rights (Davies, 1998, p. 135).

Heated debates that took place after 1997, namely on the right of abode in Hong Kong, on Hong Kong political reform, and on the regulation of Article 32 of the Basic Law, demonstrated a profound split among Hong Kong residents between those who felt loyal to Beijing and were proud of their nationality and those who identified themselves more locally and therefore felt independent from the communist regime in Beijing (BBC, 2015).According to a survey by the University of Hong Kong that asked local residents if they identified as "Hong Kongers", "Hong Kongers in China", "Chinese in Hong Kong", or "Chinese", nearly 70 percent of respondents aged 18-29 called themselves "Hong Kongers" (Ejinsight, 2017). Just 0.3 percent called themselves "Chinese". For all age groups combined, almost 68 percent of respondents identified as "Hong Kongers" or "Hong Kongers in China", compared to less than 31 percent who identified as "Chinese" or "Chinese in Hong Kong". In mid-2008, more respondents had identified as the latter than the former (Ejinsight, 2017).

\section{The derailment of Hong Kong autonomy}

The first 10 years of Hong Kong under Chinese rule shows evidence of the progressive reinforcement of central government control over the SAR and the derailment of every initiative that aims to promote Hong Kong's democratisation. Although Hong Kong's financial and entrepreneurial elite has believed in the good faith of Beijing, the pro-democracy camp has not been convinced of the sincere openness of China to meet Hong Kong's quest for democracy. In September 2002, the first elected chief executive, Tung Che-Hua, released plans for a new antisubversion law to be approved under Article 23 of the Hong Kong Basic Law. The bill was extensively rejected by the Hong Kong general public. Following Premier Wen Jiabao's visit to Hong Kong in July 2003, a march of 500,000 people against the law led to the resignation of two members of Hong Kong'sgovernment. This was the largest demonstration in Hong Kong since the handover (Bradsher, 2004). The proposal was shelved indefinitely.

In April 2004, China made clear that any change in Hong Kong's electoral system would require central government approval. That meant a veto power on any proposal that would lead to the direct election of thechief executive. In December 2004, President Hu Jintao urged the chief executive to improve his management of Hong Kong, a comment widely seen as a rebuke (Bradsher, 2004). Hu Jintao declared his belief that Hong Kong was "moving in the right direction" but warned Tung Che-Hwa that he should "sum up experiences, find out the inadequacies, sharpen administrative abilities and continue to raise the quality of governance."

Tung proved to be a very unpopular chief executive and resigned for health reasons in March 2005. Tung's chief secretary for administration, Donald Tsang Yam Kuen, was appointed acting chief executive (Martin, 2007). Tsang developed plans for a reform of Hong Kong's electoral process without introducing universal suffrage, an issue that was rejected by the Beijing government. In December of the same year, the Hong Kong pro-democracy opposition voted down this reform plan, which included the enlargement of the committee used to nominate the chief executive (to 800 members) and additional seats in the legislature (60 members) (Pan \& Ng, 2005). In April 2007, Donald Tsang was appointed for a new five-year term as chief executive after winning the preference of the election committee.

In December 2007, after returning from consultations in Beijing, Donald Tsang announced that Beijing would allow Hong Kong to directly elect its chief executive by 2017 and its lawmakers by 2020 (Hong Kong Government, 2007a). He said that "we must treasure that hard-earned opportunity" (Hong Kong Government, 2007b). 
But the initiative would not convince Hong Kong's opposition. In September 2008 the pro-democracy camp won more than one-third in legislative elections, retaining a key veto for government bills. Since the handover, there has been an intense political debate over the details of Hong Kong's independent executive, legislative, and judicial powers (Martin, 2007). Several debates took place over the selection process for the chief executive as well as the chief executive's term in office. The pro-democracy camp lobbied for additional reforms to allow the chief executive to be elected by universal suffrage among Hong Kong citizens as soon as possible. Thisresulted in reiterated opposition by Beijing. Concerning the HKSAR's legislative powers, the key issues have centredaround the composition of the Legislative Council (Legco) and the electoral process for its members. As for Hong Kong's judicial powers, the main area of concern has been the scope of its powers, particularly with respect to the interpretation of the Basic Law.

Article 158 of the Hong Kong Basic Law (HKBL)states that the power of interpretation of the Basic Law would be vested in the Standing Committee of the National People's Congress and that the same organ would "authorize the courts of the HKSAR to interpret on their own, in adjudicating cases, the provisions of this Law which are within the limits of the autonomy of the Region" (National People's Congress of the People's Republic of China, 2017). The same legal provision requires the Hong Kong courts, in cases of interpretation of articles of the Basic Law that are related to affairs that fall under the responsibility of the Central People's Government (CPG) or to the relationship between Hong Kong authorities and the CPG, to "seek an interpretation of the relevant provisions from the Standing Committee of the National People's Congress through the Court of Final Appeal of the Region". According to legal experts, the fact that the power of final interpretation of law is vested in the legislative rather than the judicial system reflects a huge ideological gap between the two legal systems (mainland and Hong Kong), which leads to conflicts when the two systems interact with one another (Chan, 2007).

The period 2007-2019 was marked by timid initiatives of political reform; the nomination of a new chief executive, C.Y. Leung; divisions in the pro-democracy camp; and the emergence of new political movements that openly claimed independence for Hong Kong. The new chief executive was elected by the political and business elite of Hong Kong, as usual, and won 689 of the 1,132 votes by members of the election committee (Bradsher, 2012). The issue of political reform was resumed in April 2010 when Hong Kong Chief Secretary Henry Tang presented the government's "Package of Proposals for the Methods for Selecting the Chief Executive and for Forming the Legislative Council in 2012" (Hong Kong Government, 2012). They included increasing the number of members of the election committee from 800 to 1,200, divided by the four traditional sectors: industrial, commercial, and financial; the professions; labour, social services, religious, and other sectors; and members of the Legislative Council and Hong Kong deputies to the National People's Congress and to the Chinese People's Political Consultative Conference. The proponents of the document considered that "Hong Kong's constitutional development should be rolled forward in 2012 and no stalemate should be allowed. This can pave the way for implementing universal suffrage in 2017 and 2020." This moderated reform faced full opposition by the pro-democracy camp, which considered it too limited.

Hu Jintao's vision for the future of Hong Kong and Macau was consistent with the orientations and the legacy of Deng Xiao Ping. In a speech at a July 2011 meeting commemorating the 90th anniversary of the founding of the Communist Party of China, President Hu stated: We will unswervingly implement the principle of "one country, two systems" under which the people of Hong Kong administer Hong Kong, and the people of Macao administer Macao with a high degree of autonomy, and fully support the governments of the Hong Kong and Macao Special Administrative Regions in governing in accordance with the law, growing their economies and improving the wellbeing of their peoples. We will promote exchanges and cooperation between Hong Kong and Macao and the mainland, unite with all forces that love the motherland, Hong Kong, and Macao, and sustain long-term prosperity and stability of Hong Kong and Macao. (Embassy of the PRC in the United States, 2011)

C. Y. Leung's appointment as chief executive responded to the necessity to have in the top job of the Hong Kong SAR someone who could comply with Beijing's instructions and who would firmly control the seeds of protest and dissidence that lay deep in Hong Kong. However, China's political elite miscalculated the depth of the sentiments of the Hong Kong people for democracy and self-governance. The public saw C. Y. Leung as a Beijing puppet, as someone who had no credentials to govern Hong Kong, no experience in the administrative sector, and no capacity for negotiation and conciliation. Since the beginning of his term as chief executive, C.Y. Leung adopted a clumsy attitude to the problems he had in his hands. He gave in to pressure regarding implementation of changes in the policy on "Moral and National Education", aiming to incorporate the nationalistic policies of China's government (Bradsher, 2012). These changes caused public wrath, as the Moral and National Education policy was seen as an act of surrender to Beijing's socialist ideology.

When President Hu Jintao swore in C.Y. Leung as Hong Kong's leader he gave clear indications of what was expected from C.Y. Leung: "We have to be aware of the fact that there remains deep conflicts and problems in Hong Kong society, which could affect Hong Kong's long-term development over the next five years" (Lim, 2012). 
On the same day of the inauguration ceremony, 400,000 people participated in a march against the nomination of the Hong Kong tycoon and the interference of China in Hong Kong's affairs.

\section{The failed leadership of C. Y. Leung and the collapse of the electoral reform}

The Chinese Communist Party held its 18th Party Congress from November 8 to November 15, 2012, where it elected 205 members of the Party Central Committee. Following the congress, the Xi Jinping administration began as he took office as general secretary of the Party and also as chairman of the Party Central Military Commission (Yamaguchi, 2012). Xi brought a breath of fresh air to the leaders of the Communist Party with a focus on "the great rejuvenation of the Chinese nation", which indicated his leaning toward nationalism: "to realize the great renewal of the Chinese nation is the greatest dream for the Chinese nation in modern history" (Gang \& Shuang, 2012; Huang, 2012). Shortly after taking office, in a nationally televised speech Xi appealed for "China's renaissance", saying,"we are at the closest point towards the Chinese nation's renaissance than any time in modern history ... and I am sure we will accomplish our goal" (Huang, 2012). Although Xi was a connoisseur of Hong Kong politics since the time he was Hu Jintao's deputy, his personal views were basically unknown in the first two years of his term as president of the republic.

The promise of the introduction of universal suffrage in electing the chief executive continued to be a major domestic issue in Hong Kong. In early 2014, Chief Executive Leung Chun-ying submitted a report to China's Standing Committee of the NPC proposing a sort of mitigated format of reform. The proposal was the result of a five-month public consultation in Hong Kong and concluded witha proposal to nominate the chief executive by a 1,200-member nominating committee. C.Y. Leung rejected the idea of civic or political party nomination as was demanded by the pan-democracy parties. Following the consultation, the Occupy Central with Love and Peace movement organised an unofficial referendum on 29-30 June (Chan\& McKirdy, 2014). Occupy Central was a pro-democracy group founded in 2013 by University of Hong Kong law professor Benny Tai Yiu-ting, Chinese University sociologist Dr Chan Kin-man, and Baptist minister Reverend Chu Yiu-ming. The movement aspired to press the Hong Kong government for bolder political reforms and was marginal to Hong Kong's more traditional opposition to China(Tang, Chow, Ngo, Nip,\& Kao, 2014). More than 90 per cent of the nearly 800,000 people taking part in the referendum vote were in favour of giving the public a say in short-listing candidates for future elections for the territory's chief executive (BBC, 2014).

The debate was fuelled by the publication on 10 June 2014 of a white paper by the State Council of China titled "The Practice of the "One Country, Two Systems"'. The paper remarked that Hong Kong already enjoyed a high degree of autonomy but the central government had comprehensive powers to govern Hong Kong, which was in compliance with the need to safeguard China's sovereignty, security, and development interests. The paper introduced a new qualification for the political and judicial personnel of the HKSAR: loving the country was a basic political requirement for Hong Kong administrators, judges, and other judicial personnel. What does "loving the country" mean? Does it mean accepting that Hong Kong is an inalienable part of China and that it is submissive in some issues to the central government directives? Or does it mean accepting the leadership of the Communist Party, being a communist, or at least being sympathetic to communist ideals? The paper didn't clarify this issue, but according to the views of the pro-democracy camp "loving the country" meant that no candidate critical of or opposed to China's communist ideology would ever be accepted as chief executive. Therefore the reform of the electoral process regarding thechief executive was a farce.

On 31 August 2014, the NPC decided unanimously that only two or three candidates receiving at least 601 votes from the 1,200-strong nomination committee could run for the office of chief executive (South China Morning Post, 2014). That decision provoked the fury of the opposition parties, who considered it much more restrictive than expected and therefore unsuitable. Chief Executive Leung Chun-ying welcomed the NPCSC decision and said that "the majority of Hong Kong citizens, namely, the 5 million qualified voters of the selection of Chief Executive in 2017, will be able to cast their votes to select the chief executive." He also said that"this is the first opportunity - a very good opportunityfor Hong Kong to have one man, one vote-universal suffrage. This is something we should all feel proud of (Stevens, 2014).

Somehow the proposal for universal suffrage in Hong Kong was not a free and fair deal, as the electorate would only be allowed to choose between candidates selected by a majority of the election commission loyal to Beijing. It was not surprising that the opposition reacted forcefully. Of the 70-member Legco, 27 members announced that they vowed to veto the plan, which requires two-thirds approval in Legco. A South China Morning Post poll conducted after China's decision found that 48 per cent of respondents thought that Legco should block the plan, which critics called "sham democracy", while 39 per cent said it should approve the framework (Sevastopulo, 2014).

Between September and November 2014 pro-democracy protesters occupied the city centre for weeks in what would become known as the "Umbrella Movement". At the height of the protests more than 100,000 people took to the streets. On 28 September 2014, police employed tear gas, pepper spray, and batons in an attempt to disperse the protesters. 
The excessive use of force in dispersing protesters antagonised and frustrated the general public and did not deter the protesters. It gave impetus to beginning occupation in other places such as Mong Kok and Causeway Bay. In November 2014, the Mong Kok protest site was cleared by the police after heavy clashes with protesters. On 12 and 15 December 2014 the sites in Admiralty and Causeway were cleared peacefully, and the protest ended (So, 2014). The reactions from the Beijingblock were harsh. Zhang Junsgheng, former deputy director of Xinhua New Agency in Hong Kong, called the referendum "meaningless" and said that the pan-democracy camp and the Occupy Central movement "have never done anything good for Hong Kong". The state-run Global Times classified the referendum as an "illegal farce" and a "joke"(Cheung\& $\mathrm{Ng}, 2014)$.

The initial reaction of the central government to the Occupy Movement was to introduce censorship on mainland Internet platforms to reduce repercussions (Cai, 2018, p. 59). But that censorship was lifted as the central government perceived that the population's reaction to Occupy Central was not positive. On 1 October the People's Daily started to attack the movement, denouncing it as illegal and urging the Hong Kong government to handle it according to the law and to duly punish the organisers. It commented that authorities would not make concessions to pro-democracy protesters in Hong Kong and that their cause was"doomed to fail" (ABC Net Australia, 2014). In a front-page editorial, the People's Daily remarked that the protesters' demands for unfettered elections were"neither legal nor reasonable", adding that "upholding the decision of the standing committee of the National People's Congress is the necessary decision, and the only decision."

Beijing had dominant influence in dealing with the protests, and is believable that C.Y. Leung reported to the central government about the Occupy Movement on a daily basis (Cai, 2018, p. 58). In the following year, Chief Executive Leung Chun-ying speculated that there was significant information indicating that foreign powers were behind the organisation of the Occupy Central movement, saying,"the interference of external forces into Hong Kong's politicsincluding a large-scale and illegal public movement such as Occupy Central—should have drawn [more] attention in the society" (...) In the past few months, large amounts of materials have been revealed ... and those people concerned did not deny the validity of such documents" (So, 2015). C. Y. Leung did not provide evidence to support the claim.

Beijing's position toward Hong Kong was that economic achievements should come first and the status quo should be maintained at all costs. The proximity of Hong Kong to China was seen both as an opportunity and as a threat in the absence of a perceived role for the SAR in China (August-Jean \& Cheung, 2018, p. 128). The overuse by C.Y. Leung of the catchword "super-connector" to characterize Hong Kong had the opposite effect of showing a Hong Kong that was losing its identity and being rapidly incorporated into China for the benefit of China and to the detriment of Hong Kong residents' quality of life.

On 18 June 2015, the Legislative Council voted down the government's proposal to introduce universal suffrage for the election of the chief executive beginning in 2017, which concluded a process of almost 18 months of intensive public debate and massive demonstrations in favour of a higher degree of democracy in Hong Kong (Kwok \& Lee, 2015). The voting revealed a highly divisive polarization in Hong Kong between the pro-establishment and the pro-democracy camps. The relationship between the executive and legislative branches continued to be strained during 2015, with opposition legislators using filibuster tactics to delay the government's initiatives. The November 2015 district elections didn't show a major change in voter preferences but brought in several new political groups, which showed that the electorate was tired of the oldformat of pro-democracy party politics and favoured a fresh restart.

After 17 years of autonomous government in Hong Kong it was clear that the chief executives nominated by Beijing, under the selection and proposal of an election committee formed by a majority of members representing the business class and Hong Kong elites, were unable to meet public expectations of a Hong Kong governed by Hong Kongers. The public felt somehow defrauded by the promises of Deng and Hu Jintao of universal suffrage for Hong Kong people in choosing their political institutions.

The year 2016 was marked by the disappearance of five booksellers from Hong Kong, the emergence of new political groups loosely described as "localists", violent clashes between protesters and the police in Mon Kok, Legislative Council elections, and the disqualification of two pro-independence lawmakers who failed to take their oaths on the terms defined by the Legco regulations in a clear defiance of China's sovereignty over Hong Kong.

In the first case, five booksellers from the Hong Kong SAR allegedly were taken to the mainland by security agents of the PRC. Four of the booksellers returned to Hong Kong in 2016, but the circumstances of their disappearance were never completely clarified. Causeway Bay Books, the store at which the men worked, had specialized in publishing gossipy books about China's leaders, and their interrogation in mainland China seemed to involve the selling of banned books on the mainland (Tsang \& Baldwin, 2016). Whether the situation was a kidnapping or not, the case of the booksellers was the most serious challenge to the "One Country, Two Systems" principle since the 1997 handover. The second case was the emergence of alternative political forces in the pro-democracy camp. 
These radical groups campaigned for the defence of Hong Kong's interests, as opposed to those of China, with some calling for self-determination or even independence. One such group was Demonisto, a group co-founded by Occupy Movement leader Joshua Wong and lawmaker Nathan Law. Law won a seat in the 2006 legislative election but was later disqualified because of a controversy over the oath-taking. The party was organised around new ideas such as selfdetermination, a break with capitalist hegemony, multiplicity, protection of the vulnerable, sexual minorities, and youth. The other movement, the Hong Kong National Party, expressed the promise to use "whatever effective means" available to push for independence, including fielding candidates in the Legislative Council elections and coordinating with other pro-independence "localist" groups. The movement didn't recognize the Basic Law and was formed by another Occupy Central activist, Chan Ho-tin (Kag-chung \& Fung, 2016). In the 2016 Hong Kong Legislative Council election, its convenor Chan Ho-tin was barred from standing due to his pro-independence stance. The novelty of these movements was that they openly attacked the principle of China's indisputable sovereignty over Hong Kong-which Beijing considers to be an act of treason.

According to media reports, at least 21 localist groups have been set up in Hong Kong.

Another important case in 2016 was the explosion on 8 February of violent clashes between protesters and the police. Some 500 protesters threw bricks and started fires, with anti-riot police responding with pepper spray and firing two warning shots into the air. The 10-hour Mong Kok riot left 128 people injured, including 90 police officers, and led to the detention of 38 protesters belonging to localist groups (Jenkins \& Iyengar, 2016). The puzzling violence was provoked by a crackdown on food vendors, with protesters later arguing that the violence that ensued was precipitated by unjust police hostility. It was the most violent protest in the city since the pro-democracy demonstrations that befell Hong Kong in the fall of 2014.

On 4 September 2016, Hong Kong held elections to select the 70 members of the Legco, and a record 2.17 million voters turned out, representing 58 per cent of the electorate. The pro-establishment camp kept the majority, but the pro-democracy camp managed to guarantee a blocking minority that could contain the government proposals (Jenkins, 2016). An interesting development was the election of several localist young candidates, who secured almost 19 per cent of the votes cast.

The former promise of non-interference in Hong Kong's affairs was put aside following the insistence of C. Y. Leung to ask for clarification from Beijing to implement his policies. During the oath-taking ceremony at the Legco, several lawmakers challenged the procedures by changing the words of the oath or repeating it in a way considered disrespectful and insulting to China (Associated Press, 2016). Two of them, Sixtus Leung and Yau Wai-ching, were barred from retaking their oath by a judicial review launched by the government. The Standing Committee of the National People's Congress decided to intervene, unanimously issuing an interpretation on the oath-taking procedure (Article 104 of the HKBL) by stating that the two legislators should be barred from retaking their oath and therefore taking up office. The fundamentals of the decision were that the oath taking was a prerequisite and a required procedure for public officers to take office, and that the oath taking must comply with the legal requirements in respect of its form and content. An oath taker is immediately disqualified from assuming public office if he or she declines to take the oath (The Standard, 2016). The interpretation was made before the court handed down its ruling rejecting the legislators' right to take their seats in the Legco.

\section{President Xi Jinping visits Hong Kong}

Xi Jinping was not a novice in Hong Kong and Macau affairs. In October 2007, after Zeng Qinghong's retirement from the Standing Committee of the Political Bureau, Xi replaced Zeng to lead Hong Kong and Macau affairs. Later he transferred this authority to Zhang Dejinag and Li Yuanbao (Zheng \& Weng, 2016, p. 44).On 29 June 2017, President Xi Jinping made his first official visit to Hong Kong since initiating his term as China's leader. The occasion was the 20th anniversary of the Hong Kong SAR and the changing of the guard in its leadership. Carrie Lam, the former deputy of C. Y. Leung, in March 2017 was voted in as the preferred candidate for the chief executive position by the electoral commission, receiving 777 out of the 1,194 eligible votes (Haas, 2017).

On his arrival, Xi pledged that China would support Hong Kong's development and improve people's livelihoods "as it always has" but affirmed that he felt the city could be doing better by saying he "sincerely wishes Hong Kong can once again achieve splendour" (Agence France-Press, 2017a). Xi accentuated that he wanted to ensure that Hong Kong's "one country, two systems" set-up, which is enshrined in the handover deal and gives it rights unseen on the mainland, "is on a stable, long lasting path". Xi praised the government for "dealing a blow" to the independence movement and complimented Leung for his "firm" handling of the city and dealing with what he called "accumulated problems". 
Later that day, while inspecting the garrison of the People's Liberation Army sited in Hong Kong, he added that In the 20 years since Hong Kong was returned to the motherland, the success of "one country, two systems" is recognized by the whole world. Of course, during the implementation, we've met some new situations, new issues and new challenges. On these issues, they need to be regarded correctly and analyzed rationally... Issues are not scary. The key is to think of ways to solve these issues. (Torose \& $\mathrm{Wu}, 2017$ )

At the welcome dinner held by the government of the Hong Kong SAR, Xi severely reminded the Hong Kong elites of their duty of obedience to the People's Republic of China and its leadership: "The SAR system established under the Constitution of the People's Republic of China and the Basic Law of the Hong Kong Special Administrative Region has operated effectively, and democracy in Hong Kong has been advanced in accordance with law" (Xinhua, 2017). He added, "the multiple indicators of governance of the HKSAR such as government effectiveness and the rule of law are much higher than those before Hong Kong's return to the motherland (...) such achievements would not have been possible without the strong support of the Central Government and the mainland, they are primarily attributed to the unity and hard work of the HKSAR Government and people of Hong Kong."

The tone was harsh even in the ceremony to mark the 20th anniversary of the return to China and the swearing in of Carrie Lam. Xi warned that Beijing would not tolerate any challenge to its authority and even mentioned a red line: "any attempt to endanger China's sovereignty and security, challenge the power of the central government and the authority of the Basic Law of the HKSAR or use Hong Kong to carry out infiltration and sabotage activities against the mainland is an act that crosses the red line and is absolutely impermissible" (Reuters, 2017; Today, 2017). While pledging Beijing's support for the "one country, two systems" blueprint under which Hong Kong returned to Chinese rule in 1997, Xi was even starker: "Hong Kong needs to improve its systems to uphold national sovereignty, security and development interests. It needs to enhance education and raise public awareness of the history and culture of the Chinese nation" (Reuters, 2017). The message of complete subordination of Hong Kong's interests and liberties to China's dominant sovereignty and political supervision was clearly transmitted to the first female chief executive, Carrie Lam.

The reactions to the speeches were surly. Jean-Pierre Cabestan, professor at the Hong Kong Baptist University, said that the address laid out "a very strong warning against dissenters" as Xi acted as "schoolmaster warning there will be consequences if they misbehave" (Agence France-Press, 2017b). William Lam, professor at the Chinese University of Hong Kong, said, "the message is quite clear that 'one country' towers over 'two systems' as Xi asked Hong Kong people to obey instructions because the sovereign power overrides everything". The reaction by pro-democracy advocate Claudia Mo was also caustic, saying, "he wanted to instil fear and respect, or respect out of fear, from Hong Kong people".

\section{Conclusion}

The sanguine prospects for an easy handover of Hong Kong and Macao to China, according to the "One Country, Two Systems" principle, clashed with the very ambiguity of this principle and the reality of new leadership in Communist China, who somehow broke up with the line of "soft authoritarianism", to adopt David Shambaugh's interesting qualification, adopted byJiang Zemin and Hu Jintao in line with Deng Xiaoping's legacy. Xi Jinping is not a "Dengist", as his political line is closer to that of Mao Zedong than to Deng.

During the first years of life of Hong Kong and Macau as Chinese SARs, the evolution of their political institutions toward a model consistent with the Western traditions of constitutional and human rights seemed to be something possible and everlasting. But with the passage of time it became evident that the progress of the model of representation toward a system of election for the chief executive and the Legco by universal suffrage was not an inevitability; it was just a desire, an aspiration of the Hong Kong people, a narrative that part of the Hong Kong elite believed.

The chief executives who led the HKSAR after the handover had the thorny task of not closing the door to the proposals of the pro-democracy camp, but at the same time they knew that Beijing, according to the Basic Law, was sceptical and would have the last word.

The leadership shift in the Chinese Communist Party and in the central government from the hands of Hu Jintao to Xi Jinping introduced an additional factor of contingency when it was perceived that the political priorities of $\mathrm{Xi}$ and the role he saw for China in the world were not compatible with the framework of decentralized powers that the existence of the two SARsrepresented. In championing a war against corruption within mainland China, Xi knew that part of the problem was located in Hong Kong, and that controlling the footpaths of the "tigers and flies" would require the reinforcement of control over Hong Kong and demanding absolute loyalty from the Hong Kong administration. 
Therefore the catchword "high degree of autonomy for the SARs" and even "autonomy" started to disappear from the official speeches, and people started to believe that something had changed in China discourse regarding Hong Kong. The catchwords now were "sovereignty", "love of the motherland", and "national unity". More than a change in the rhetorical style, the shift meant that the subsistence of democratic institutions in territories that are part of the PRC is unlikely and in the longrun undesirable. China wants to continue as a socialist state led by the Communist Party, the resident power in China.

The period after the handover has also featured the depletion of the pro-democracy camp in Hong Kong, accompanied by the ageing of its leadership (Emily Lau, Democratic Party; Alan Leong Kah-kit, Civic Party, Johnny Mak, Democratic Alliance, Lee Cheuk-yan, Hong Kong Confederation of Trade Unions), creating conditions for the emergence of political groups of young people who don't view themselves in the core political parties. They started to propose policies that were against Hong Kong's status quo.

The Occupy Central movement and the "localist" parties that emerged from it reveal that the parties of the system mobilize a dwindling number of people. The new generations will find a way, probably a different way, to fight for an identity for Hong Kong within the PRC and eventually out of it. The taboo of self-determination for Hong Kong is no more a taboo. Everything is left open.

\section{References}

ABC Net Australia. (2014, October 3). Hong Kong protests: Scuffle between protesters as students refuse to leave streets. Retrieved from http://www.abc.net.au/news/2014-10-03/hong-kong-police-scuffle-with-protesters/5788834

Agence France-Presse. (2017a, June 29). China's President Xi arrives to a divided Hong Kong. News 24. Retrieved from https://m.news24.com/World/News/chinas-president-xi-arrives-in-divided-hong-kong-20170629

Agence France-Press. (2017b, July 2). Xi Jinping leaves Hong Kong smarting. Retrieved from https://www.ndtv.com/world-news/schoolmaster-xi-jinping-leaves-hong-kong-smarting-1719480

Associated Press (2016, October 19).Hong Kong lawmakers walk out to block swearing-in of democracy activists. The Guardian. Retrieved from https://www.theguardian.com/world/2016/oct/19/hong-kong-lawmakers-walk-outdemocracy-activists-china

August-Jean, L., \& Cheung, A. (2018). The economic roots of the umbrella movement in Hong Kong: Globalization and the rise of China. London: Routledge Contemporary China Series.

BBC. (2014, June 30). Hong Kong democracy "referendum" draws nearly 800,000. Retrieved from http://www.bbc.com/news/world-asia-china-28076566

BBC (2015, June 18). Hong Kong's democracy debate. Retrieved from http://www.bbc.com/news/world-asia-china27921954

Bradsher, K. (2004, December 21). President of China warns Hong Kong's leader to do a better job. The New York Times. Retrieved from https://www.nytimes.com/2004/12/21/world/president-of-china-warns-hong-kongsleader-to-do-a-better-

job.html?mtrref=www.google.com\&gwh=72B0EBA7DAAD7D460BEB7483E61C1BB2\&gwt=pay

Bradsher, K. (2012, March 25). Hong Kong, divided over future, gets a new leader. The New York Times. Retrieved from

https://www.nytimes.com/2012/03/26/world/asia/hong-kong-divided-over-future-gets-a-newleader.html?mtrref=www.google.com\&gwh=318F5C0ED11CB1FD13DAAED162383BE9\&gwt=pay

British Embassy (1984, December 19). Record of a meeting between the prime minister and the chairman Deng Xiaoping at the Great Hall of the People, Peking. Beijing: Margaret Thatcher Foundation. Declassified December 2014. Retrieved from

http://7f11a30961219bd1a71e-

b9527bc5dce0df4456f4c5548db2e5c2.r10.cf1.rackcdn.com/841219\%201600\%20MT-

Deng\%20memcon\%20PREM19\%201502\%20f41.pdf

Cai, Y. (2018). The Occupy Movement in Hong Kong: Sustaining decentralized protest. London: Routledge Contemporary China.

Chan, J. (2007). Basic Law and constitutional review. The first decade. Hong Kong Law Journal, 37(2), 407-447. Retrieved from https://hub.hku.hk/bitstream/10722/87975/3/content.pdf?accept=1

Chan, M.,\& Clark, D. (Eds.) (1991). The Hong Kong Basic Law. Blueprint for "stability and prosperity" under Chinese sovereignty?. Hong Kong: Hong Kong University Press. 
Chan, W., \& McKirdy, E. (2014, June 30). Hong Kong's Occupy Central democracy "referendum"-What you should know. $C N N$. Retrieved from https://edition.cnn.com/2014/06/24/world/asia/hong-kong-politics-explainer/index.html

Cheung, G., \& Ng, J. (2014, June 24). Former Xinhua official Zhang Junsheng calls Hong Kong's unofficial poll meaningless. South China Morning Post. Retrieved from http://www.scmp.com/news/hongkong/article/1539237/former-xinhua-official-zhang-junsheng-calls-hong-kongs-unofficial

Davies, M. (1988). Where two legal systems collide: An American constitutional scholar in Hong Kong. School of Law. Case Western Reserve University. Case Western Reserve Journal of International Law, 20(1), 127-146. Retrieved from https://scholarlycommons.law.case.edu/cgi/viewcontent.cgi?article=1698\&context=jil

Deng Xiaoping (1987). Fundamental issues in present-day China. Beijing: Foreign Languages Press.

Ejinsight (2017, December 28).Only 0.3\% of young Hongkongers see themselves as Chinese: survey. Retrieved from http://www.ejinsight.com/20171228-only-0-3-percent-of-young-hongkongers-see-themselves-as-chinesesurvey/

Embassy of the People's Republic of China in the United States of America (2011, July 1). Full text of Hu Jintao's speech at CPC anniversary gathering. Retrieved from http://www.china-embassy.org/eng/gdxw/t836140.htm

Fernandes, M. (2017, June). As negociações assimétricas: Portugal, China e Macau. Relações Internacionais, 54. Retrieved from http://www.scielo.mec.pt/scielo.php?script=sci_arttext\&pid=S1645-91992017000200010

Fischer, M., \& Klatte, S. (2011, March), Decolonization: Portuguese territories. In Max Planck Encyclopedia of Public International Law [MPEPIL]. Retrieved from http://opil.ouplaw.com/view/10.1093/law:epil/9780199231690/law-9780199231690-e927

Fundação Jorge Alvares (n.d.). Neutralidade de Macau na Guerra do Ópio. Retrieved from http://www.fundacaojorgealvares-bibliotecadigital.com/civil-e-cultura-china-e-macau/macau-guerra-do-opio/

Gang, W., \&Shuang, Y. (2012, November 30). Xi Jinping pledges "great renewal of Chinese nation". Global Times. Retrieved from http://www.globaltimes.cn/content/747443.shtml

Ghai, Y. (2003) Foreword in Loh, C. \& Civil Exchange, Building democracy. Creating good governance for Hong Kong. Hong Kong: Hong Kong University Press.

Government of Hong Kong Special Administrative Region of Hong Kong (2017, April 28), Basic law full text. Retrieved from http://www.basiclaw.gov.hk/en/basiclawtext/index.html

Haas, B. (2017, March 26). Hong Kong elections: Carrie Lam voted leader amid claims of China meddling. The Guardian. Retrieved from https://www.theguardian.com/world/2017/mar/26/hong-kong-chooses-new-leaderamid-accusations-of-china-meddling

Hong Kong Government. (2007a).Decision of the standing committee of the National People's Congress on issues relating to the methods for selecting the chief executive of the Hong Kong Special Administrative Region and for forming the legislative council of the Hong Kong Special Administrative Region in the year 2012 and on issues relating to universal suffrage. Retrieved from http://www.legco.gov.hk/yr0708/english/panels/ca/papers/ca0121-ppr071229-e.pdf

Hong Kong Government. (2007b, December 29). Donald Tsang hails NPCSC decision. Retrieved from http://archive.news.gov.hk/isd/ebulletin/en/category/administration/071229/html/071229en01002.htm

Hong Kong Government. (2012). Package of proposals for the methods for selecting the chief executive and for forming the legislative council in 2012. Retrieved from http://www.cmab-cd2012.gov.hk/doc/package/package_e.pdf

Huang, C. (2012, November 30). Xi Jinping pledges renewal of the nation. South China Morning Post. Retrieved from http://www.scmp.com/news/china/article/1094272/xi-jinping-pledges-renewal-nation

Information Office of the State Council, The People's Republic of China (2014, June 10). White paper on "One Country, Two Systems" policy in Hong Kong.South China Morning Post. Retrieved from http://www.scmp.com/news/hong-kong/article/1529167/full-text-practice-one-country-two-systems-policyhong-kong-special

Jenkins, N. (2016, September 5). Hong Kong legislative elections have given voice to a new political generation. The Time. Retrieved from http://time.com/4478978/hong-kong-legislative-council-election-legco/

Jenkins, N., \& Iyengar, R. (2016, February 9). Hong Kong sees violent start to Chinese new year as protesters clash with police. The Time. Retrieved from http://time.com/4213191/hong-kong-riot-protest/

Joint Declaration of the Government of the United Kingdom of Great Britain and Northern Ireland and the Government of the People's Republic of China on the Question of Hong Kong with Annexes, 5. (1987).Berkeley Journal of International Law, 5(6). Retrieved from http://scholarship.law.berkeley.edu/bjil/vol5/iss2/6. 
Ka-chung, N.,\& Fung, O. (2016, March 28). Hong Kong national party is born: Will push for independence, will not recognise the basic law. South China Morning Post. Retrieved from http://www.scmp.com/news/hongkong/politics/article/1931384/hong-kong-national-party-born-will-push-independence-will

Kwok, D., \& Lee, Y. (2015, June 18). Hong Kong vetoes China-backed electoral reform proposal. Reuters. Retrieved from https://www.reuters.com/article/us-hongkong-politics-idUSKBNOOY06320150618

Lim, L. (July, 2012, July 1). Anger grows In Hong Kong over China, new leader. North Country Public Radio. Retrieved from https://www.northcountrypublicradio.org/news/npr/156067222/anger-grows-in-hong-kongover-china-new-leader

Macau Special Administrative Region. (n.d.). Joint declaration of the Government of the People's Republic of China and The Government of the Republic of Portugal on the question of Macao. Macao Government Printing Bureau. Retrieved from http://bo.io.gov.mo/bo/i/88/23/dc/en/

Martin, M. (2007, June 9). Hong Kong: Ten years after the handover. CRS Report for Congress. Washington: Congress Research Service. Retrieved from https://fas.org/sgp/crs/row/RL34071.pdf

Ministry of Foreign Affairs of People's Republic of China. (n.d.). Resumption by China of the exercise ofsovereignty over Macao. Retrieved from http://www.fmprc.gov.cn/mfa_eng/ziliao_665539/3602_665543/3604_665547/t18052.shtml

National People's Congress of the People's Republic of China (2004, March 14). Constitution of the People's Republic of China. Retrieved from http://www.npc.gov.cn/englishnpc/Constitution/node_2825.htm.

National People's Congress of the People's Republic of China (2017, December 12). The Basic Law of the Hong Kong Special Administrative Region of the People's Republic of China. Retrieved from http://www.npc.gov.cn/englishnpc/Law/2007-12/12/content_1383894.htm

Pan, P., \& Ng, K. (2005, December 22). Hong Kong rejects modest reforms. Washington Post. Retrieved from http://www.washingtonpost.com/wp-dyn/content/article/2005/12/21/AR2005122101466.html?noredirect=on

Parlamento Português(n.d.). Constituição da República Portuguesa. Texto originário da Constituição, aprovada em 2 de Abril de 1976. Retrieved from https://www.parlamento.pt/parlamento/documents/crp1976.pdf

Reuters (2007, June 29). Chronology: Timeline of 156 years of British rule in Hong Kong. Retrieved from https://www.reuters.com/article/us-hongkong-anniversary-history-idUSSP27479920070627

Reuters (2017, July 1). Xi swears in Hong Kong's new leader, calls any challenge to Beijing "impermissible". Japan Times. Retrieved from https://www.japantimes.co.jp/news/2017/07/01/asia-pacific/hong-kong-hit-protestschinas-xi-swears-citys-new-leader/\#.Ww5pkdEUm_4

Roblin, S. (2016, August 1). The Opium Wars: The bloody conflicts that destroyed imperial China. The National Interest. Retrieved from http://nationalinterest.org/blog/the-buzz/the-opium-wars-the-bloody-conflictsdestroyed-imperial-china-17212?page $=2$

Scott, H. (n.d.). Macau and the Europeans. Retrieved from www.howardscott.net/4/Macao_A.../MacaoAndTheEuropeans.pdf

Sevastopulo, D. (2014, September 15). Hong Kong divided over Beijing's proposal for democracy. Financial Times. Retrieved from https://www.ft.com/content/07a65246-3c83-11e4-a6ce-00144feabdc0

So, P. (2014, December 14). Hundreds of police to clear Hong Kong's last pro-democracy protest site. South China Morning Post. Retrieved from http://www.scmp.com/news/hong-kong/article/1661842/police-outline-detailsclearance-causeway-bay-occupy-site

So, P. (2015, January 13). CY Leung repeats claim of "external forces" influencing Occupy—but provides no evidence. South China Morning Post. Retrieved from http://www.scmp.com/news/hong-kong/article/1679392/cy-leungreiterates-claim-external-forces-influencing-occupy-provides

South China Morning Post (2014, August 31). Full text: NPC Standing Committee decision on Hong Kong 2017 election framework. Retrieved from http://www.scmp.com/news/hong-kong/article/1582245/full-text-npcstanding-committee-decision-hong-kong-2017-election

Stevens, A. (2014, September 5). Beijing says no to open elections in Hong Kong. CNN. Retrieved from https://edition.cnn.com/2014/08/31/world/asia/hong-kong-elections

Tam, C. (n.d.). The Sino-Portuguese dispute over the holder of sovereignty of Macao and the friendship and trade treaty between China and Portugal from an international law perspective. Review of Culture. Retrieved from http://www.icm.gov.mo/rc/viewer/20019/1014

Tang, E., Chow, V., Ngo, J., Nip, A., \& Kao, E. (2014, September 30). CY Leung digs in as he admits Occupy Central protests could last "a long time", South China Morning Post. Retrieved from http://www.scmp.com/article/1604384/hong-kong-wakes-third-day-civil-disobedience

The Standard (2016, November 7). Article 104. The full text of the PRC interpretation. Retrieved from http://www.thestandard.com.hk/breaking-news.php?id=81866 
Today (2017, July 1). China's Xi warns Hong Kong to toe the line as he swears in new leader. Todayonline.com. Retrieved from https://www.todayonline.com/chinaindia/china/carrie-lam-sworn-hong-kongs-fourth-chiefexecutive

Torose, G., \& Wu, V. (2017, June 29). Hong Kong faces "challenges". U.S. News. Retrieved from https://www.usnews.com/news/world/articles/2017-06-29/chinas-president-xi-inspects-hard-workingcomrades-at-hong-kong-garrison

Tsang, S., \& Baldwin, C. (2016, June 16). Hong Kong bookseller says associate abducted by China authorities. Reuters. Retrieved from https://www.reuters.com/article/us-hongkong-bookseller-idUSKCN0Z21GG

University of Macau (n.d.). Basic Law Macau. Retrieved from http://www.umac.mo/basiclaw/english/main.html

Wen Qing (2009, May 26). One country two systems: The best way to peaceful reunification. Beijing Review. Retrieved from http://www.bjreview.com.cn/nation/txt/2009-05/26/content_197568.htm

Willets, P. (2013). The United Nations, self-determination and the Falkland Islands. Talk at a public meeting at the Falkland Islands Chamber of Commerce. Retrieved from http://www.staff.city.ac.uk/p.willetts/SAC/COMMENTS/PW080313.PDF

Willies. C. (Ed.) (2002). China and Macau. Aldershot, Hampshire, UK: Ashgate.

Wong, J., \& Ngo, J. (2016, November 8). How China stripped Hong Kong of its right to self-determination in 1972and distorted history. Hong Kong Free Press. Retrieved from https://www.hongkongfp.com/2016/11/08/chinastripped-hong-kong-right-self-determination-1972-distorted-history

Xiao Weiyun. (2001).One country, two systems. An account of the drafting of the Hong Kong Basic Law. Peking: Peking University Press.

Xinhua. (2017, July 1). Full text of speech by President Xi Jinping at welcome dinner in HK. Xinhuanet.com. Retrieved from http://www.xinhuanet.com/english/2017-07/01/c_136407943.htm

Yamaguchi, S. (2012). The 18th Chinese Communist Party Congress and Xi Jinping. Retrieved from http://www.nids.mod.go.jp/english/publication/briefing/pdf/2012/briefing_e171.pdf

Zheng Yongnian, \& Weng Cuifen. (2016). The development of China's formal political structures. In R. Ross\&J. Bekkevold (Eds.),China in the era of Xi Jinping. Domestic and foreign policy challenges. Washington, DC: Georgetown University Press. 